\title{
FAMILY LAW AND FRENCH LAW IN VANUATU: AN OPPORTUNITY MISSED?
}

\author{
Sue Farran*
}

This article outlines the need for the courts in Vanuatu to adopt a more robust approach in developing a relevant regional jurisprudence by considering certain aspects of French family law which remain potentially applicable under the Constitution of Vanuatu as law existing at independence. With reference to selected areas of family law, it explains how a more vigorous comparative approach using French law may be useful for filling gaps which presently exist in national legislation and also illustrates how certain dimensions of French family law may be particularly suited to the contemporary Vanuatu context.

Les dispositions de la constitution de Vanuatu reconnaissent encore un plein effet à nombre de textes français qui régissaient le droit de la famille avant l'accession à l'indépendance. Cet article déplore, qu'en dépit de ce cadre juridique existant, les juridictions de Vanuatu n'ont pas toujours recours à ces règles. L'auteur milite pour une prise en compte quasi-systématique des dispositions françaises par les juridictions de Vanuatu. Elle estime que si tel devait être le cas, cela devrait permettre un développement d'une véritable jurisprudence régionale cohérente. S'intéressant plus particulièrement à certains aspects du droit de famille, l'auteur explique comment par le recours à une méthode comparative en utilisant le droit français, on pourrait dans de nombreuses situations combler les imprécisions et les lacunes de la législation nationale de Vanuatu. L'auteur explique enfin, comment certaines dispositions du droit de famille français peuvent être particulièrement adaptées aux structures familiales que connaît le Vanuatu contemporain.

\section{INTRODUCTION}

The impetus for this article arose in the course of compiling a Digest of Family Law for Vanuatu. Although Vanuatu has been independent since 1980, there has been very little national legislation passed with respect to family law as other matters have been more pressing and given greater priority. It is also the case that most family matters are resolved within the confines of the family or the wider community, often through the intervention of traditional dispute mechanisms such as village councils or chiefs, and also community religious leaders. However, social change 
brought about by economic development, urbanisation and modernisation has led to increased litigation regarding family matters. For this reason, it was felt desirable to bring together the various laws which regulate family affairs.

Due to the historical evolution of Vanuatu there is a plurality of sources of law. This is particularly so with regard to family law. According to the Constitution, until the national Parliament passed its own legislation French and English law would continue to be applicable in varying degrees. ${ }^{1}$ This included all Joint Regulations made when Vanuatu was the New Hebrides under the Condominium government of France and Britain, and also British and French laws in force or applied in Vanuatu immediately before the Day of Independence unless expressly revoked or incompatible with the independent status of Vanuatu.

It is not clear exactly what the law at the date of independence was. In the case of law which was introduced from Britain it seems that it was probably written law - statutes of general application - up until 1976, and Queen's Regulations passed for the Western Pacific by the British High Commissioner of the Western Pacific, and Regulations made by the Resident Commissioner for the New Hebrides.

In the case of law from France, it would seem that it was written law in force in France, including Regulations made by the French High Commissioner of the Pacific and applicable to Vanuatu up until 1980. This included the French Civil Code at that date except where the provisions of the Code had been replaced by a Joint Regulation. ${ }^{2}$

The law in force in 1980 also included Joint Regulations, and subsidiary legislation, which were made by the British and French Resident Commissioners for the New Hebrides, and from 1977 resolutions passed by the elected Representative Assembly which were approved by the Resident Commissioners and enacted as Joint Regulations.

* Associate Professor of Law, University of the South Pacific, Emalus Campus, Vanuatu.

1 Constitution of Vanuatu, art 95:

(1) Until otherwise provided by Parliament, all Joint Regulations and subsidiary legislation made thereunder in force immediately before the Day of Independence shall continue in operation on and after that day as if they had been made in pursuance of the Constitution and shall be construed with such adaptations as may be necessary to bring them into conformity with the Constitution.

(2) Until otherwise provided by Parliament, the British and French laws in force or applied in Vanuatu immediately before the Day of Independence shall on and after that day continue to apply to the extent that they are not expressly revoked or incompatible with the independent status of Vanuatu and wherever possible taking due account of custom.

2 Colardeau v Mammelin [1980-94] Van LR 1; Luthier v Kam [1980-94] Van LR 116; Pentecost Pacific Ltd v Hnaloane [1980-94] Van LR 134; My v Societe Sariani [1980-94] Van LR 163. 
In addition to legislation drawn from Britain and France, the jurisprudence of the courts was also relevant, and remains so today. Under Article 95 of the Constitution, general principles of law and equity (which derive from case law) are a source of law - subject to compatibility with the independent status of Vanuatu, the provisions of the Constitution and considerations of custom where applicable - until replaced by legislation. This means that the courts may have recourse to decisions of the United Kingdom courts and to decisions of the French courts up until independence in 1980. There is no reason to believe that the 1976 cut-off date applicable to English statutes applied to general principles of law and equity. The Queen's Regulation No 2 of 1976 which established the High Court of the New Hebrides refers to "statutes of general application in force in England on the $1^{\text {st }}$ day of January, 1976", not to the general principles of law and equity. ${ }^{3}$ General principles which have developed through case law after 1980 may be persuasive, as may those from other jurisdictions.

Besides these aspects of law introduced under the influence of the two colonial powers, customary law remains important. This is stressed in the Constitution, which states that customary law shall continue to have effect as part of the law of the Republic of Vanuatu. ${ }^{4}$ Also - and this is important for family law - in applying the written law which existed at the time of independence, wherever possible, "due account" must be taken of custom. Custom is defined in the Schedule to the Interpretation Act Cap 132 as: "the customs and traditional practices of the indigenous peoples of Vanuatu". However, ascertaining custom is not easy. First, most custom is unwritten. Secondly, there is no uniform national custom. ${ }^{5}$ Under Article 51 of the Constitution:

Parliament may provide for the manner of the ascertainment of relevant roles of custom, and may in particular provide for persons knowledgeable in custom to sit with the judges of the Supreme Court or the Court of Appeal and take part in its proceedings.

However, apart from the provisions made for the appointment of assessors knowledgeable in local customs to assist in land matters, ${ }^{6}$ little has been done in this respect. The National Council of Chiefs (the Malvatumauri) also has power under Article 30 of the Constitution to discuss and to make recommendations, particularly on any question relating to tradition and custom. ${ }^{7}$ Although it

3 The Queen's Regulation 1976, no 2, s 3.

4 Constitution of Vanuatu, art 95(3).

5 There are approximately 110 different cultures or groups within the 80 islands of Vanuatu.

6 Under the Island Courts Act 1983, no 10, there is provision for the appointment of assessors to sit in the Supreme Court when it sits as an appeal court: under section 2, the court hearing an appeal against a decision of an island court shall appoint two or more assessors knowledgeable in custom to sit with the court.

7 Under Article 30 of the Constitution of Vanuatu the National Council of Chiefs: 
does discuss such matters and sometimes makes recommendations these are rarely published and appear to have no binding authority.

Lawyers may bring matters of custom to the attention of the courts, but any claims based on custom must be adequately proved to the satisfaction of the court. Although the usual rules of evidence may be waived, in particular the rule against admissibility of hearsay evidence, the court must still be sufficiently convinced that the custom is as claimed. An indication of how customary law may be argued is indicated in the case of Banga $v$ Waiwo, where the judge stated: ${ }^{8}$

The most common means of ascertaining and proving customary law is by oral testimony of expert witnesses or by witnesses who are not experts in customary law that is, witnesses of fact. The difference being that the latter are not qualified to give opinions on what customary laws are, but are limited to testifying as to certain historical events from which a court may reach a decision as to law.

Sometimes when customary law is relied on in family cases it is insufficiently argued; in other cases no evidence as to custom is presented. In such cases, although there may well be custom governing the matter, the court must rely on other sources of law.

It has recently been suggested by the Court of Appeal of Vanuatu, that, where there is no provision made in national legislation to deal with a matter, then the law in force at independence must be referred to. ${ }^{9}$ The case in question concerned two francophone residents of Vanuatu. The dispute was about the division of property on divorce. While national legislation, namely the Matrimonial Causes Act Cap 192 of Vanuatu, provides for divorce, it makes no reference to the division of the property of the spouses. ${ }^{10}$ Despite the acknowledged origins of the litigating spouses, counsel for neither party based their arguments on French law, even though it is clear from the Constitution that this could have been done. Why not? The answer is sad but simple. The lawyers were not familiar with French law. One was from New Zealand and the other from Australia. Although both had been in practice in Vanuatu for some time, their knowledge and experience was essentially based on common law. The judge in the Supreme Court was from England and the judges of the Court of Appeal from New Zealand, Fiji, and Australia. Only one

(1) has a general competence to discuss all matters relating to custom and tradition and may make recommendations for the preservation and promotion of ni-Vanuatu culture and language; and

(2) may be consulted on any question, particularly any question relating to tradition and custom, in connection with any bill before Parliament. children. Often the division of family property will follow from any awards made by the court under these headings. 
was from Vanuatu, and he indeed would have understood arguments based on French law, having been educated in both systems. ${ }^{11}$ It is not, however, the position of the bench to present legal argument. The logistics of this case reflect a serious problem and poverty in the Vanuatu legal system. Potentially, there is the possibility of drawing on the rich variety of legal sources available due to its unique legal pluralism. In practice this does not happen.

The purpose of this article is to indicate why recourse to French family law as it existed at independence should not be overlooked and how reference to certain aspects of French law may be not only very useful for filling the gaps which presently exist in national legislation, but also to illustrate how some dimensions of French family law may be particularly suited to the Vanuatu context. To this end attention will be drawn to certain aspects of French law which seem to be especially pertinent and relevant to contemporary Vanuatu.

\section{FRENCH FAMILY LAW}

The family law which is relevant is that found in the provisions of the Civil Code - modified by legislation - as it existed in 1980, except in so far as these had been altered or replaced by regulations made by the French High Commissioner of the Western Pacific, or regulations made by the Resident French Commissioner of the New Hebrides. ${ }^{12}$

Although prior to independence French law only applied to French citizens and optants - and English law to British subjects and optants - following independence and, eventually, the definitive judgment of the Court of Appeal in the case of Banga $v$ Waiwo: ${ }^{13}$

[U]nder Article 95 of the Constitution, the French and English laws that applied on the day before the day of independence applied to everyone in Vanuatu, irrespective of nationality and irrespective as to whether they were indigenous ni-Vanuatu or not.

There are no clear guidelines as to when French or English law might be followed. If a case was started under French law under the Condominium then it tended to be resolved under French law post-independence and vice versa. ${ }^{14}$ Alternatively, the nationality of the defendant may be relevant, ${ }^{15}$ although this would appear to contradict the reasoning in Banga $v$ Waiwo of one

11 Chief Justice Lunabek is a francophone who received some of his legal training in France. He is the first indigenous person to hold the position of Chief Justice.

12 The New Hebrides appears to have been regarded as French territory: Dihn van Tho v Etat Francaise [198088] 1 Van LR 16.

13 Banga $v$ Waiwo, above n 8, 5.

14 Banga $v$ Waiwo, above n 8, 5; T v R [1980-88] 1 Van LR 7; Selb Pacific Ltd v Mouton [1996] VUSC 4.

15 Pentecost Pacific Ltd v Hanaloane, above n 2. 
(pluralistic) system for all regardless of nationality. ${ }^{16}$ There have, moreover, been cases where aspects of both French and English law have been applied. ${ }^{17}$

Where there is no national law on the matter, then it would seem that there is the option, stated in Banga $v$ Waiwo, for the courts to "proceed under the existing Vanuatu English or French laws". ${ }^{18}$ If there is a conflict, or perhaps a choice of two alternative paths to follow, then the courts have a constitutional duty to resolve the matter and do substantial justice. ${ }^{19}$ Arguably, in order for the courts to do this, counsel must present the full range of options, including, of course, reference to custom where possible and also to international conventions. ${ }^{20}$

The constitution and dicta from cases not only permit but support a pluralistic approach. For example, referring to other common law jurisdictions, Chief Justice d'Imecourt stated that: ${ }^{21}$

[T] he courts of Vanuatu are not bound by any decisions of any of those courts. ... It can thus enrich its own jurisprudence by putting to good use and effect, those rules of law which have proved wise and successful and have been well tested in other jurisdictions. ...

It has also been suggested that part of an Act or written law in force at independence may apply rather than the whole. ${ }^{22}$

16 "[I]t is clear that under Article 95 of the Constitution, the French and English laws that applied on the day before the Day of Independence applied to everyone in Vanuatu. ... They were no longer French or English laws but they became the law of Vanuatu": Banga $v$ Waiwo, above n 8, para 14 d'Imecourt J.

17 Leigh v Societe Civile Inter-Continental and Groupement Francais d'Assurance [1980-1988] 1 Van LR 76; Societe Civile Familiale Guadrou v Prouds South Seas Ltd [1980-1988] 1 Van LR 100. See further the cases cited in Banga v Waiwo, above n 8, and J Care "Colonial Legacies" (1997) 21 J Pac Stud 33.

18 Banga $v$ Waiwo, above n 8, para 14.

19 There is no right of election. This was abolished when the Protocol of 1914 establishing the Condominium was repealed on the Day of Independence. This does not, however, mean that lawyers cannot present different alternatives to the court.

20 M Pruss points out that the French version of what is now Article 95 of the Constitution states that English and French laws will apply "in so far as they are not incompatible with custom" which places greater emphasis on custom than the English version which states that "due account of custom" should be taken "wherever possible": M Pruss French Law in the New Hebrides (LLM Thesis, Emalus Library, University of the South Pacific, Vanuatu) 77 (emphasis added).

21 Timakata v Attorney General [1989-94] 2 Van LR 575. The judge appears to have been referring solely to common law jurisdictions but there is no reason why a broader approach cannot be taken by an independent country.

22 Coombe $v$ White [1980-88] 1 Van LR 340; Joli $v$ Joli, above n 9. 


\section{THE FAMILY LAW OF THE CIVIL CODE}

Reference to the French Civil Code is found in cases decided during the 1980s, indicating that it clearly was part of the law post-independence. ${ }^{23}$ Although in France much of the Code has been amended over the years by legislation and elaborated upon by the jurisprudence of the courts, the family law which applied in Vanuatu pre-independence in 1980 remained untouched by the changes which occurred in 1985, again in the 1990s and even in the first years of this new century. It was, therefore, a family law grounded in ideas that observed the husband as head of the family, but which had also adapted in 1965 to recognise the autonomy and ability of a wife to earn her own living and participate in the administration and management of family matters, including family finances. It was a family law that took into account principles of equality of the sexes, but also recognised the reality of inequality in terms of earning capacity, material wealth and likely financial dependency. It was a family law in which marriage remained central and cohabitation was not yet equated with marriage. However, it was also a period of family law when, increasingly, children - whether legitimate or not - were being perceived as needing equal protection and as having equal claims on their parents. In many ways, therefore, French law pre-1980 reflected many of the aspects of the family which are found in Vanuatu today, where strong traditional patriarchal structures prevail but are having to be modified by equal rights provisions in the Constitution and pressures to observe standards articulated in the international conventions to which Vanuatu is a signatory, notably the Convention on the Rights of the Child and the Convention on the Elimination of Discrimination Against Women (CEDAW). ${ }^{24}$

There are, of course, many differences between the situation in Vanuatu and the context in which French law of pre-1980 developed, but consideration of certain aspects of the Civil Code which, if the principle of Joli $v \mathrm{Joli}^{25}$ is to be taken in its widest sense, remain potentially applicable may illustrate why there is a case to be made for bringing French law back into the courts. To this end, the focus of this article will be on various aspects of French law and children, French law and the relationship between spouses, and French law and vulnerable people. These are all areas where very little national legislation exists and where there may well be scope for enlarging the law by referring to what already exists within recognised sources of law, rather than waiting for Parliament to take action.

23 Colardeau v Mammelin, above n 2; Luthier v Kam, above n 2; Pentecost Pacific Ltd v Hnaloane, above n 2; My v Societe Sariani, above n 2.

24 These are the most relevant for family law. The Convention on the Rights of the Child (7 July 1993) was ratified by the Convention on the Rights of the Child (Ratification) Act 1992, no 26, and the Convention on the Elimination of all Forms of Discrimination Against Women (7 September 1995) was ratified by the Convention on the Elimination of all Forms of Discrimination Against Women (Ratification) Act 1995, no 34.

25 Joli $v$ Joli, above n 9, para 15; paras 17-19. 


\section{FRENCH LAW AND CHILDREN}

The law relating to children in Vanuatu is underdeveloped. Although Vanuatu is a signatory to the Convention on the Rights of the Child, little has been done in the way of national legislation to make specific provisions to give effect to this Convention. ${ }^{26}$ A person is a child until the age of 18. ${ }^{27}$ Under the Constitution, a parent has a fundamental duty to: ${ }^{28}$

Support, assist and educate all his children, legitimate and illegitimate, and in particular to give them a true understanding of their fundamental rights and duties and of the national objectives and of the culture and customs of the people of Vanuatu.

Children are an important human resource in Vanuatu, where it is estimated that 37 per cent of the fast-growing population is under the age of $14 .^{29}$ Yet there is no compulsory education, and national reports published by the United Nations Children's Fund (UNICEF) indicate that while 96 per cent of children go to primary school, only 25-30 per cent of these proceed to secondary school. ${ }^{30}$

Apart from provisions in the criminal law directed at punishing the neglect of children and sexual offences against children, domestic law has been passed regarding the maintenance of children. The Maintenance of the Family Act Cap 42 governs maintenance of legitimate children, while the Maintenance of Children Act Cap 46 governs that of illegitimate children. The latter Act contains fairly limited provisions regarding affiliation of such children. ${ }^{31}$ The Matrimonial Causes Act Cap 192 also contains provisions relating to the maintenance of children in the case of divorce. Most of this legislation is brief in outline and often needs to be supplemented, either by the

26 Some protection can be found in the Penal Code Cap 135 and in the Employment Act Cap 160.

27 Interpretation Act Cap 132, sch 2.

28 Constitution of Vanuatu, art 7(h).

291999 Population and Household Census. The total population then was 186,678. It is now estimated to be 200,000. The growth rate estimated in the census was 1.74 per cent.

30 UNICEF Country Programme Overview <http://www.unicef.org/infobycountry/vanuatu_statistics.html> (last accessed 22 May 2004). These figures represent the period 1995-2001. Unpublished figures presented at a Symposium in 2001 suggest the rate is lower: D Hughes "Qualitative Study on Child Protection Practices: Vanuatu Draft Report" (Symposium, University of the South Pacific, 2001).

31 Under the Maintenance of Children Act Cap 46, s 3, an unmarried mother may bring a claim for maintenance against the alleged father of the child if there is evidence that either during the period of conception there was an offer of marriage, or during the same period the parties lived together as husband and wife, or that the man alleged to be the father at some time provided for the child's maintenance and upbringing in a paternal capacity, or that the man alleged to be the father admitted paternity. 
jurisprudence of the courts - for example, by reference to the general principles found in international law - or by reference to pre-independence law. ${ }^{32}$

There is no national legislation on matters of adoption, guardianship, custody or access in cases other than divorce, or elaborating the general constitutional rights and duties owed by a parent to a child. In most cases custom and customary law will govern the rights of children and the duties of parents and indeed under the Constitution, wherever possible, custom must be taken into account. ${ }^{33}$ Sometimes, however, customary law is not pleaded before the court, ${ }^{34}$ is found to be incompatible with the Constitution, ${ }^{35}$ or must give way to international standards or norms. ${ }^{36}$

French law, however, has some useful provisions which could not only assist the courts in determining disputes involving children, but also help to clarify the rights and status of children.

First, the Civil Code has provisions relating to the apparent status of children based on the facts surrounding a child's upbringing, naming and relationship with the apparent parents. ${ }^{37}$ Given that informal customary adoption is quite common in Vanuatu, especially among members of the extended family or clan, this might provide a way of formalising the status of a child, a step which can be particularly important in claiming land or title rights.

Similarly, French law includes the notion of voluntary acknowledgement of paternity or maternity, where made in accordance with the personal law of the person making that acknowledgement. ${ }^{38}$ Thus, paternity acknowledged in custom can be accommodated. There are also very clear guidelines regarding the rebuttable presumption of paternity, ${ }^{39}$ and the law relating to the legitimation of children who are born illegitimate. ${ }^{40}$ Both of these legal issues are unprovided

32 As was the case in Joli v Joli, above n 9, where, because the Matrimonial Causes Act Cap 192 makes no reference to the allocation of matrimonial property on divorce, the court referred back to English preindependence law.

33 Constitution of Vanuatu, art 95(2).

34 For example, in the case of Re Chelsea Lee [2000] VUSC 22 - even though this was a case where an indigenous child was being adopted by an Australian couple; and in Re the Constitution, Infant Vorongo [1986] VUSC 4 - where the customary consequences of bride-price payments were noted but not customary adoption even though the child appeared to have been "placed" for adoption before any formal adoption took place.

35 Public Prosecutor v Kota and Others [1993] VUSC 8.

36 Molu v Molu [1998] VUSC 15.

37 Civil Code, art 311.

38 Civil Code, arts 311-317.

39 Civil Code, arts 312-328.

40 Civil Code, arts 329-333. 
for by national law in Vanuatu, but are extremely important for the purposes of inheritance, especially of land.

A further area, which is neglected by national law, is the establishment of paternity - separate from a claim for maintenance by the unmarried mother. French law allows a claim for paternity to be brought either by the child or the mother against the purported father or his heirs within two years of the child's birth. ${ }^{41}$ This claim is separate from a claim for support, which in French law can be brought even if paternity is not established. ${ }^{42}$

French law also stipulates very clearly the duties which parents owe to their children and the powers which they have over them. ${ }^{43}$ While, in Vanuatu, custom and the influence of the church will guide many parents, in a society facing rapid social and economic change family relations are increasingly under pressure. The Convention on the Rights of the Child also creates expectations that Vanuatu will ensure that all children will receive the protection of the law. ${ }^{44}$ Indeed, this could well be an area where Vanuatu may be expected to introduce reform, and certainly there is some lobbying for this by non-governmental organisations.

The provisions of the Civil Code complement both the Constitution and the Convention. Children are expected to respect their parents regardless of age, and to be governed by them until majority. In return, children have the right to expect their parents to safeguard their personal security, health and moral well-being and to have their educational needs taken into account. Parents also have a duty to ensure that contact with grandparents is maintained - an important consideration in the Melanesian extended family. ${ }^{45}$ Equally relevant to today's circumstances in Vanuatu, which is witnessing urban drift of young people at an alarming rate, is article 371.3 of the Civil Code, under which a child cannot leave the family home without the permission of his or her parents.

Because the law establishes these parental duties, it also provides sanctions and procedures whereby breaches or abuse can be addressed. The advantage of this regime is that disputes between

41 Civil Code, art 340 (pre-1993 version). The right to establish paternity is important for claiming land rights under patterns of customary land tenure. The period of two years is longer than that provided for under national legislation, which is one year.

42 Civil Code, art 342. This probably does not apply in Vanuatu as national legislation regarding maintenance has been passed - Maintenance of Children Act Cap 46.

43 Civil Code, arts 371-389.

44 Convention on the Rights of the Child, above n 24, preamble; art 4.

45 These duties and obligations apply equally between parents whether married or not, provided, in the latter case, that both parents recognise the child within a year of birth and live together, or on application to the court - an important point in a country where an increasing number of relationships are not formalised even in custom. Parental authority can also be removed by the court in certain circumstances: Civil Code, arts 373 and 378. 
parents may be referred to an independent and objective arbitrator - an approach which may be particularly important in a society which is still strongly patriarchal and where women tend to be dominated and intimidated by men. Arguably, in the Vanuatu context, the adjudicative forum need not be a court, and there may be scope here for incorporating some kind of traditional forum, exercising powers in accordance with national guidelines and working with the family members. ${ }^{46}$

French law also provides a formal means whereby a tutor or guardian can be appointed by a court when both parents are dead, or, in the case of an illegitimate child, the mother is dead - if only the mother recognises the child - or the parent or parents cannot be found or are in some way incapable. ${ }^{47}$ While in practice, in Vanuatu, the next of kin may take on this role informally, there is merit in having some formality, not only to avoid later confusion or uncertainty, but also to ensure that the best interests of the child are being observed. This is particularly important as parental authority confers the right to administer the minor's property and represent the minor in legal matters. $^{48}$ Again, there is no reason why the extended family should not be involved in such an appointment and indeed French law gives an important role to the family council. ${ }^{49}$

The Civil Code also makes extensive provision for the process and consequences of adoption, especially the rights of the adopted child. ${ }^{50}$ While in Vanuatu customary adoption is recognised alongside formal adoption through the court, ${ }^{51}$ no national legislation has been passed to govern formal adoption and procedures for customary adoption vary from one community to another. ${ }^{52}$ Because custom changes and is not consistent, and because increasingly people from different customary groups are inter-marrying and people are moving from one location to another, there can be uncertainty about the status of a customary adoption. It is increasingly common to find applications for adult adoption coming before the court to formalise informal or customary adoption which may have taken place some time previously. English law does not provide for adult adoption. French law does. ${ }^{53}$ Moreover, as in the appointment of a tutor or guardian, in the case of adoption under French law the family council has an important role to play and the impact of the adoption on third parties' rights is considered. While, due to the influence of the Convention on the Rights of the

46 There are no family courts or specialist judges or lawyers in Vanuatu. At the same time there is no such thing as national custom, as custom is not homogenous throughout the Republic, hence the need for clear national guidelines.

47 For example, due to insanity, absence or disappearance, or involvement in criminal activity.

48 Civil Code, arts 382-387.

49 See for example, Civil Code, arts 407-441.

50 Civil Code, arts 343-372.

51 See for example, $M v P$, re the Child G [1980-1994] Van LR 333.

52 See Tebahai $v$ Habi [1986] VUSC 9.

53 Civil Code, art 360 
Child, the welfare of the child will be the predominate concern in cases involving adoption, ${ }^{54}$ it may be important to construe this within the specific context of Vanuatu, lacking, as it does, any social services network to act as a safety net. ${ }^{55}$ Custom and introduced universal norms may well be in conflict here, and the involvement of the family council within a structured framework could help to achieve a balance which both ensures the best interests of the child, and addresses those interests realistically, taking into account, where necessary, traditional or customary approaches.

\section{FRENCH LAW AND THE RELATIONSHIP BETWEEN SPOUSES}

Marriage in Vanuatu is regulated by the Marriage Act Cap 60 and the Control of Marriage Act Cap 45. Neither Act indicates the rights and duties of the spouses towards each other. ${ }^{56}$ In English law these rights and duties have emerged in a fragmented fashion through decisions of the courts over the centuries, often strongly influenced by the religious creeds. In French law, while such influences also have their place, the Civil Code contains very specific provisions detailing the relationship between husband and wife; it also has extensive provisions concerning matrimonial property.

Articles 203-226 of the Civil Code stipulate the obligations arising from marriage. In particular, the law emphasises the mutuality and reciprocal nature of rights and obligations between spouses, thereby giving support to ideals of equality between the sexes, as found in the Constitution of Vanuatu and in the provisions of CEDAW. ${ }^{57}$ At the same time, the reality of possible inequality, especially in a material sense, is recognised and addressed, so, for example, need and ability to provide are balanced. ${ }^{58}$

As regards the administration of matrimonial matters, French law veers towards the patriarchal model - found in the customary law of the region - but has built in safeguards to prevent the abuse of that power. For example, it contains requirements of consent, ${ }^{59}$ and the possibility of applying to the court to annul the exercise of a power which amounts to an abuse of that power. ${ }^{60}$ Furthermore, the joint and several liability of parents for the maintenance and education of their children and of

54 Convention on the Rights of the Child, art 21.

55 See further Sue Farran "Approaches to Child Custody in the Pacific Region" in Law School Occasional Papers (University of the South Pacific, Vanuatu, 2003) occasional paper no 3; K Brown "Customary Law and the Welfare Principle" (1997) 21 J Pac Stud 83.

56 By implication the duty of support arises because failure to support attracts criminal and civil sanctions under the Penal Code Cap 135 and the Maintenance of Family Act Cap 42.

57 Convention on the Elimination of Discrimination Against Women, above n 24 .

59 Civil Code, arts 217-219.

60 Civil Code, arts 220-221. 
spouses towards the expenses of the household make it clear that the family and the partnership of two individuals is central to marriage.

Also, unlike English law, where marriage does not alter the property interests of the individual spouses, ${ }^{61}$ French law recognises from the outset the practical property consequences of marriage. Although questions of matrimonial property arise most often in the case of the termination of the marriage, by divorce or death, they can also arise as regards third party creditors during the marriage. Vanuatu law makes no provision for the property consequences of marriage during the marriage and very limited provisions for the allocation of property on divorce or death. In the case of divorce, there is provision relating to the payment of alimony to the wife and maintenance to the children, but no reference to the allocation of matrimonial property. ${ }^{62}$ On death, there is national legislation which covers testate succession, ${ }^{63}$ but none which deals with intestate succession. ${ }^{64}$

French law, however, makes detailed provision for the property consequences of marriage, whereby either spouse can opt for a particular property arrangement and enter into a legal agreement concerning this, or, by default, be governed by a statutory regime which applies automatically if no other is chosen. ${ }^{65}$ The advantage of French law, in this regard, is that once it is ascertained which matrimonial regime applies, then the powers of administration and management of the property are determined, as are the relationship and rights of spouses towards third parties, and the portion which each spouse will be entitled to on divorce or dissolution of the matrimonial regime, or on death. In short, the Civil Code provides a formula which addresses most of the property consequences and expectations of marriage.

\section{FRENCH LAW AND VULNERABLE PEOPLE}

While the law in Vanuatu gives limited recognition to vulnerable people, ${ }^{66}$ absence of any State provision and very limited medical facilities for those who are mentally impaired in any way means that the burden and responsibility of caring for vulnerable people falls on the family. Where such people come to the attention of the courts - either as victims or perpetrators - the courts are often at a loss as to how to deal with them. The courts, especially the Supreme Court, have jurisdiction "to

61 Under the Married Women's Property Act 1882, the property of a married woman, whether brought to the marriage or acquired thereafter remains her own and separate from that of her husband as does his.

62 Matrimonial Causes Act Cap 192, considered in Joli v Joli, above n 9.

63 Wills Act Cap 55.

64 In many cases custom will govern this, especially in the case of customary land, which cannot be alienated.

65 See Sue Farran "What is the Matrimonial Property Regime in Vanuatu?" (2001) 5 JSPL Working Paper 4 $<$ http://law.vanuatu.usp.ac.fj/jspl> (last accessed 22 May 2004).

66 Notably through the criminal offence of neglect - Penal Code Cap 135, s 104 - and procedural safeguards under the Rules of Civil Procedure 2002, no 49, rule 3.8. 
hear and determine any civil or criminal matter",67 and, using its inherent power, the Supreme Court may make a person a ward of court. ${ }^{68}$ However, French law has detailed provisions for the protection - either total or partial - of vulnerable people. While not all of these would be practical in the circumstances of Vanuatu, especially those based on the assumption of State provision, a number would, especially those which involve the participation of the family or responsible individuals.

In particular, French law recognises that there are situations falling short of insanity or certifiable mental illness where a person may need protection from themselves or others. ${ }^{69}$ It is not necessary under French law that an adult be insane to justify the appointment of a tutor or guardian. Any evidence of an inability to look after his or her affairs sensibly may be sufficient: for example profligacy, wastefulness, intemperance, greed, or excessive generosity may all be grounds, if this weakness of character or inclination threatens to cause destitution or prevent the carrying out of family obligations. It is also recognised in French law that these moments of incapacity may be of temporary or permanent duration and that adjustments have to be made accordingly. Similarly, the gravity of the impairment may vary considerably and so different limits to the exercise of the normal rights and duties of an adult have to be provided for. To this end different protection regimes are offered.

As with children, the family council is involved in the protection of adults with impaired capacity, both in the application for a protection regime and in the appointment of a suitable person, and, in many cases, in determining the powers which are given to that person and overseeing the exercise of these. ${ }^{70}$ In a country where there are no mental institutions, extremely little psychiatric health care and no social services to support the families of impaired adults, the possibility of arriving at a solution through the co-operation of the court and the family is an important one. While at present the burden rests on the family and the local community, a more formalised system could result in better protection of vulnerable adults, who, at present may be subject to abuse, social ostracism and denial of fundamental rights. At the same time, those striving to live with or look after such an adult may be unsure of the extent to which they can interfere with that adult's affairs.

\section{WHY FRENCH LAW?}

Apart from the Constitutional provisions which clearly give French law equal status with English law as regards laws in force at independence - and subjects them to the same caveats - it

67 Constitution of Vanuatu, art 49(1).

Mermer v Mermer [1996] VUSC 13.

69 Civil Code, arts 488-514.

70 See for example, Civil Code, arts 493 and 497. 
can be argued that because French law is codified it is immediately more accessible. ${ }^{71}$ Although codification rarely achieves the sometimes stated aim of making the law available to the people, it certainly makes the law more easily available to lawyers. ${ }^{72}$ Compare, for example, the law on guardianship in English law where more than five statutes may apply, ${ }^{73}$ with the provisions to be found together in the Civil Code. ${ }^{74}$ Similarly, in the case of the English law of adoption reference must be made to at least four pieces of legislation, ${ }^{75}$ whereas in the Civil Code the law can be found in Articles 343-370. ${ }^{76}$

Of course it can be argued, with French law as with English law, that this introduced law is not compatible or suitable for the circumstances of Vanuatu. Indeed, it may be argued that where there is no national written law then customary law should prevail. However, if the provisions of Article 95 are read together with the Court of Appeal's approach to filling legal lacunae in the case of Joli $v$ $\mathrm{Joli},{ }^{77}$ it is not necessary to adopt introduced law in its entirety, but possible to select as and when necessary. Further, as indicated above, there are aspects of French law which appear to have the potential to accommodate and complement existing customary aspects of society and family organisation, thereby observing the combined provisions of Article 95 of the Constitution. Aspects of French law may, therefore, either be resorted to as an interim "gap-filling" expedient, or, when law reformers get around to family law, as a possible model to be considered. ${ }^{78}$

\section{CONCLUSION}

The purpose of this article has been to demonstrate that the legal system of Vanuatu offers its people a wealth of potential legal solutions to family issues which are not being utilised as effectively as they could. This deficit is not just limited to family law but is well illustrated by it.

71 The language argument against using French law cannot be raised because there is no hierarchy given to French or English under the Constitution which preserves both languages and adds a third, Bislama.

72 Collecting the law into one volume is certainly not an alien idea in Vanuatu. A consolidation of the laws of Vanuatu (legislation) was made in 1985.

73 Guardianship Act 1986, Guardianship Act 1925, Guardianship and Maintenance of Infants Act 1951, Guardianship of Minors Act 1971 and Guardianship Act 1973.

74 Civil Code, arts 389-514.

75 The Adoption of Children Act 1926, Adoption of Children (Regulation) 1939, Adoption Act 1958, Children Act 1975 and Adoption Act 1976 (which consolidated the law).

76 Moreover copies of the Code Civil often include reference to the jurisprudence which interprets or enlarges the scope of articles, as well as statutes which have modified the provisions of the Code.

77 Joli $v$ Joli, above n 9.

78 At present new legislation tends to be strongly influenced by Australian models, sometimes to the extent of inappropriate cut and paste techniques, due largely to heavy reliance on Australian donor-funded consultants engaged in legal drafting. 
Ignorance on the part of lawyers - including legislative draftsmen - and the general public is largely to blame. Lawyers and indeed magistrates and judges prefer to stick with what they know and what they are used to. Despite the constitutional provisions relating not only to French law as a source of law, but also the equality given to the French language, in practice both are, by and large, ignored in the courts. There is a strong possibility that, as a result of disuse, French law will simply cease to be a source of law in the not so distant future. This is a pity, not least because there are a number of young francophone lawyers entering practice, albeit largely trained in common law. ${ }^{79}$ If French law is to survive then there has to be more lawyers who can offer it to their clients and bring it to the attention of the courts. This can be done partly at least by increasing the number of lawyers who are francophone, or bilingual. Perhaps it should be a professional requirement that all lawyers are conversant with at least two of the three official languages, and trained in the civil law - provided they can focus on pre-1980 law. ${ }^{80}$ Alternatively, or additionally those lawyers currently in practice - common law lawyers - could be encouraged to become more familiar with French civil law. The latter would require some kind of continuing education programme supported by political and professional will. ${ }^{81}$ There also needs to be more client awareness that indeed they have a right to look to French law if there is no national law on the matter, and they have a right to expect to be able to find a lawyer who can assist them in their quest.

In the meantime what can be done? A practical solution would be to create consultancy partnerships between common law and civil law lawyers, either both located in Vanuatu or located in different countries. ${ }^{82}$ This is a solution which is not uncommon to legal practice in respect of sharing expertise and often crosses geographical boundaries. At present, Vanuatu lawyers are by and large isolated from civil law lawyers and vice versa. ${ }^{83}$ Similarly, efforts should be made to create legal education programmes which specifically address the needs of Vanuatu lawyers, for example, by way of combined undergraduate and post-graduate provision for law students and those

79 Most are graduates of the University of the South Pacific but there are also some law graduates who have studied civil law in New Caledonia or indeed in France. It is very rare to find a lawyer trained in both common law and civil law.

80 Such lawyers have to be admitted to practice and to achieve this they must overcome the hurdles created by the Legal Practitioners Act Cap 119 amended by Legal Practitioners (Amendment) Act 2001, no 18, and Legal Practitioners (Qualifications) Regulations Act 1996, no 22.

81 Given that there is no mandatory requirement for continuing professional development in Vanuatu compared to many other more developed countries - it is difficult to see how lawyers could be persuaded to do this unless it was provided for free, or unless the currently passive Law Society decided to initiate such a programme.

82 Provided such civil lawyers are mindful of the need to refer to pre-1980 French law.

83 Although they may well have links with Australian and New Zealand law firms for consultancy purposes. 
already practicing. ${ }^{84}$ Legal literacy in the region needs to encompass accessible information about all the laws available and not just some of them, a task which requires financial and human resources. ${ }^{85}$ Some initiatives have been undertaken in this respect, notably, the translation and consolidation of the laws of Vanuatu into French. This is an ongoing task and not only is there a backlog of early national legislation still to be translated, but pre-independence legislation still needs to be located and incorporated. If anglophone lawyers are to use this pre-independence law then that too has to be translated, from French to English. Longer term, it would be desirable to have a Law Reform Commission, which could consider the various possible approaches taken by French, English and customary law in order to create the most suitable national family (and other) laws for Vanuatu.

It will be some time before the national legislature has replaced all the laws which were in force at independence, especially in the field of family law. Until then there is a choice, but without some practical measures being taken that choice will be theoretical rather than real and will become increasingly illusionary until, one day, it will have disappeared altogether.

84 Initiatives at post-graduate level are being explored by the University of the South Pacific and the New University of Polynesia. It is also possible for francophone common law students registered at the University of the South Pacific to receive part of their undergraduate studies in French via the University of Moncton in Canada and Université Jean Moulin (Lyon 3) in France under the Campus Numerique programme transmitted to the Agence Universitaire Francaise in Port Vila.

85 Some legal literature is now being produced in the three official languages of Vanuatu, notably by the Community Legal Centre of the University of the South Pacific, and other NGOs. 
